ks. Zbigniew Janczewski

\title{
Dopuszczenie do sakramentów wtajemniczenia osoby w nieregularnej sytuacji małżeńskiej
}

Sakramentami wtajemniczenia chrześcijańskiego są chrzest, bierzmowanie i Eucharystia. W Katechizmie Kościoła Katolickiego czytamy, że stanowią one fundament życia chrześcijańskiego. Uczestnictwo w Boskiej naturze, które otrzymują w nich ludzie, objawia pewną analogię do powstania, rozwoju i wzrostu życia naturalnego człowieka. Odrodzony przez chrzest - zostaje umocniony w bierzmowaniu, aby w Eucharystii otrzymać pokarm życia wiecznego ${ }^{1}$.

W niniejszym przedłożeniu zajmiemy się niezwykle trudnym problemem udzielania wspomnianych sakramentów osobie pozostającej w tak zwanej nieregularnej sytuacji małżeńskiej, czyli żyjącej w kolejnym związku (na wzór małżeństwa), który nie jest ważnym lub sakramentalnym małżeństwem. W pierwszej części zostaną omówione zasady dopuszczania do interesujących nas sakramentów, przewidziane przez Kodeks prawa kanonicznego. Kolejna dotyczy kwestii przygotowania dorosłych do wtajemniczenia chrześcijańskiego. W trzeciej części opracowania zostanie

1 Zob. Katechizm Kościoła Katolickiego [dalej: ккк] 1212. 
dokonana próba oceny sytuacji osób żyjących w związkach nieregularnych w świetle najnowszego dokumentu papieskiego Amoris laetitia, natomiast na zakończenie zajmiemy się już bezpośrednio rozwiązaniem problemu postawionego w tytule tego przedłożenia.

\section{Zasady dopuszczania do sakramentów wtajemniczenia chrześcijańskiego według Kodeksu prawa kanonicznego}

Dopuszczanie do sakramentów wtajemniczenia chrześcijańskiego dokonuje się według zasad przewidzianych przez prawo kanoniczne. Norma kodeksowa zezwala na udzielanie sakramentów jedynie osobom, które właściwie o nie proszą, są odpowiednio przygotowane, a prawo nie zabrania im przyjęcia tych środków zbawczych ${ }^{2}$. W Xxi wieku raczej nie udziela się sakramentów dorosłym niezwracającym się do duszpasterzy o możliwość ich przyjęcia. Szczególnie przed sakramentami wtajemniczenia chrześcijańskiego przeprowadza się odpowiednie przygotowanie kandydatów. Czasami jednak prawo zabrania udzielenia sakramentu proszącemu. Przyjrzymy się temu w dalszej części opracowania.

Warunkiem chrztu dorosłego jest wyrażenie przez niego woli bycia ochrzczonym, pouczenie go o prawdach wiary oraz obowiązkach wynikających z bycia chrześcijaninem, a także przejście specjalnego okresu przygotowawczego, nazywanego katechumenatem. Taką osobę powinno się również zachęcić do wyrażenia skruchy za popełnione grzechy33. Cały proces przygotowania i przysposobienia dorosłych do chrztu dokonuje się w ramach specjalnie zorganizowanego w tym celu katechumenatu, opierającego się na wskazaniach wydanych przez konferencję biskupów, a także

\footnotetext{
2 Zob. Kodeks prawa kanonicznego [dalej: KPK 1983], kan. 843 § 1.

3 Zob. kan. 865 § 1 KPK 1983.
} 
bardziej szczegółowych unormowaniach biskupa diecezjalnego ${ }^{4}$ Wymaganie wzbudzenia w sobie żalu za grzechy jest związane z godziwością przyjęcia tego sakramentu ${ }^{5}$.

Mniej rygorystyczne warunki muszą być spełnione w przypadku przyjmowania pierwszego sakramentu wtajemniczenia przez dorosłego w niebezpieczeństwie śmierci. Wystarczy wtedy, że posiada on jakąś znajomość głównych prawd wiary, w jakikolwiek sposób ujawni intencję przyjęcia sakramentu i przyrzeknie, że w przyszłości będzie zachowywał nakazy religii chrześcijańskiej6. Wymagania są zatem podobne, należy jednak uwzględnić szczególne okoliczności, w których znajduje się proszący o sakrament ${ }^{7}$. W bezpośrednim niebezpieczeństwie śmierci wystarczy stwierdzenie występowania u proszącego - w dowolny sposób wyrażonej - woli prowadzenia chrześcijańskiego życia po ustąpieniu wspomnianego niebezpieczeństwa ${ }^{8}$.

Jeżeli jakaś poważna racja nie stoi na przeszkodzie, dorosły zaraz po chrzcie powinien zostać bierzmowany i uczestniczyć w Eucharystii, przyjmując Komunię św. ${ }^{9}$ Wydaje się, że ustawodawca przewidział $\mathrm{w}$ tej normie pojawienie się przeszkód uniemożliwiających udzielenie kolejnych sakramentów wtajemniczenia, czyli odejście od zasady jedności tychże sakramentów podczas sprawowania pierwszego z nich. Przeszkodą będzie na pewno brak możliwości użycia olejów, chleba czy wina przy bierzmowaniu i celebracji Mszy Świętej. Zdatnym do bierzmowania jest

4 Zob. J. Krzywda, Chrzest, w: Komentarz do Kodeksu prawa kanonicznego, red. J. Krukowski, t. 3/2, Poznań 2011, s. 52.

5 Zob. M. Pastuszko, Prawo o sakramentach św. Normy ogólne i sakrament chrztu, Warszawa 1983, s. 182.

6 Zob. kan. 865 § 2 КРК 1983.

7 Zob. D. Composta, L'ufficio Della Chiesa di santificare, w: Commento al Codice di Diritto Canonico, ed. V. Pinto, Roma 1985, s. 532.

8 Zob. J. Krzywda, Chrzest, w: Komentarz..., s. 53.

9 Zob. kan. 866 KРК 1983. 
chrześcijanin, który wcześniej nie przyjął drugiego z sakramentów wtajemniczenia. Aby przyjęcie sakramentu było jednak godziwe, oprócz spełnienia warunku używania rozumu i odpowiedniego pouczenia kandydat powinien być właściwie dysponowany, mogąc odnowić przyrzeczenia chrzcielne. Wymagania odnoszące się do godziwości nie mają zastosowania w przypadku wystąpienia niebezpieczeństwa śmierci ${ }^{10}$. Właściwa dyspozycja dotyczy pozo-

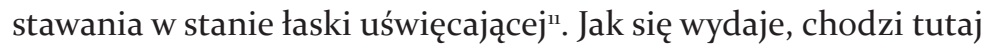
o stan w momencie przyjmowania bierzmowania, czyli że w tej ważnej chwili przyjmujący powinien mieć odpuszczone wszystkie popełnione wcześniej grzechy ciężkie. Jeżeli bierzmowanie następuje zaraz po chrzcie, warunek ten jest spełniony niejako automatycznie, bo chrzest zmywa wszystkie grzechy człowieka, wraz z pierworodnym.

Zgodnie z normą kanoniczną do Komunii św. dopuszcza się ochrzczonego, o ile nie zabrania mu tego prawo ${ }^{12}$. Według Józefa Krzywdy prawo ogranicza uprawnienie do przyjmowania Eucharystii z powodu braku przygotowania przyjmującego, pełnej jedności z Kościołem katolickim, popadnięcia w kary kościelne oraz uporczywego trwania w jawnym grzechu ciężkim. Te ograniczenia wymagają ścisłej interpretacji ${ }^{13}$. Jak się wydaje, osoby rozwiedzione, które żyją z nowymi partnerami jak w małżeństwie, mogą być uznane za trwające $\mathrm{z}$ uporem $\mathrm{w}$ ciężkim grzechu jawnym, jeżeli ich sytuacja jest znana w szerszym środowisku, np. w pracy, w większej grupie rodziny lub przyjaciół. Zdarzają się jednak przypadki, że para taka jest uznawana przez otoczenie, a nawet przez swojego duszpasterza za żyjącą w przykładnym małżeństwie

\footnotetext{
10 Zob. kan. 889 KPK 1983.

1 Zob. J. Krzywda, Chrzest, w: Komentarz..., s. 77.

12 Zob. kan. 912 KPK 1983.

13 Por. kan. 913, 96, 804, 915 KPK 1983; J. Krzywda, Chrzest, w: Komentarz..., s. 98.
} 
katolickim. We wspomnianej sytuacji brakuje przesłanki występowania grzechu publicznego.

Do Komunii św. nie powinna przystępować także osoba posiadająca świadomość ciążącego na jej sumieniu jakiegokolwiek grzechu ciężkiego. Grzech taki musi być najpierw odpuszczony podczas sakramentu pokuty albo przez wzbudzenie w sobie aktu żalu doskonałego (o ile istnieje ku temu poważna racja i nie ma możliwości wyspowiadania się) ${ }^{14}$. Jeżeli Komunia jest udzielana w triadzie sakramentów wtajemniczenia, podobnie jak w przypadku bierzmowania uznaje się, że przyjmujący posiada wspomnianą dyspozycję.

\section{Przygotowanie osoby dorosłej do przyjęcia sakramentów wtajemniczenia}

Po analizie norm dotyczących zasad dopuszczania osób dorosłych do interesujących nas sakramentów przejdźmy do kwestii przygotowania do tego istotnego momentu życia. Będą nas interesowały przede wszystkim kwestie, które mogą się łączyć z sytuacją osób żyjących w tzw. związkach nieregularnych.

Specyfiką katechumenatu, przygotowującego do chrztu i pozostałych sakramentów wtajemniczenia, jest przyjęcie formy stanu, formy bycia chrześcijaninem jeszcze przed momentem pełnego włączenia do Kościoła. Już w starożytności chrześcijańskiej kandydaci musieli gwarantować szczerość swoich intencji między innymi poprzez zaprzestanie uprawiania zawodów niezgodnych z chrześcijaństwem. Pogańscy kapłani, strażnicy świątyń pogańskich, producenci przedmiotów używanych przy uprawianiu kultu, zajmujący się magią, astrologią, wróżbami, nierządem czy zdegenerowanymi formami sportu winni byli zmienić uprawianą profesję, w przeciwnym bowiem razie nie dopuszczano ich

14 Zob. kan. 916 KРК 1983. 
do katechumenatu. Od małżonków wymagano zachowywania wierności, a od pozostałych - czystości. Osoby, które w okresie przygotowania popełniły grzech ciężki, odsyłano do pokutujących, w przypadku zaś recydywy odsuwano definitywnie od wspólnoty chrześcijańskiej ${ }^{15}$. Kryterium dopuszczania do chrztu opierało się na trzech elementach: żalu za grzechy, wierze w Kościół oraz radykalnej zmianie życia ${ }^{16}$. Chrzest, do którego przygotowywali się katechumeni, był „kąpielą na odpuszczenie grzechów”, stąd też domagano się całkowitego zerwania z nimi i szczególnego, gruntownego nawrócenia ${ }^{17}$.

Do starożytnego katechumenatu nawiązują obowiązujące Obrzędy chrześcijańskiego wtajemniczenia dorostych, będąc równocześnie głęboko osadzonymi w warunkach życia Kościoła współczesnego ${ }^{18}$. W Katechizmie Kościoła Katolickiego czytamy natomiast, że formacja katechumenów ma na celu umożliwienie im, w odpowiedzi na Bożą inicjatywę i w łączności ze wspólnotą eklezjalną, osiągnięcia dojrzałości w nawróceniu i wierze ${ }^{19}$. Jak podaje Czesław Krakowiak, okres katechumenatu to czas intensywnej formacji, wewnętrznego duchowego dojrzewania i wychowywania do chrześcijańskiego stylu życia, dokonujący się przez nawrócenie, katechezę i liturgię ${ }^{20}$.

15 Zob. B. Nadolski, Liturgika. Sakramenty, sakramentalia, błogosławieństwa, t. 3, Poznań 1992, s. 23.

16 Zob. M. Dujarier, Krótka historia katechumenatu, Poznań 1982, s. 45-46.

17 Zob. K. Mikołajczuk, Realizacja zasady jedności sakramentów wtajemniczenia chrześcijańskiego w prawodawstwie Kościoła katolickiego, Kielce 20o6, s. 51.

18 Zob. A. Durak, Inicjacja chrześcijańska dorostych, w: Misterium liturgii w Katechizmie Kościoła Katolickiego, red. J. J. Kopeć i in., Opole 1995, s. 52; K. Mikołajczuk, Realizacja zasady..., s. 263.

19 Zob. КкК 1248.

20 Zob. C. Krakowiak, Katechumenat chrzcielny dorostych w Kościele posoborowym, Lublin 2003, s. 313. 
Zgodnie ze wspomnianymi powyżej obrzędami jeden z etapów wtajemniczenia, nazywany „okresem oczyszczenia i oświecenia”, odbywa się po dopuszczeniu kandydata, odznaczającego się „nawróceniem serca i zmianą obyczajów, a także dostateczną znajomością nauki chrześcijańskiej”" ${ }^{21}$ Natomiast skrutynia, które uroczyście celebruje się w niedziele, prowadzą do uwolnienia od grzechu i szatana oraz umocnienia w Chrystusie ${ }^{22}$.

Przygotowanie dorosłych do przyjęcia chrztu i pozostałych sakramentów wtajemniczenia zarówno w czasach apostolskich, wczesnego chrześcijaństwa, jak i obecnie podkreśla zatem konieczność zmiany życia kandydata. Chodzi tutaj o zmianę radykalną. Musi on zdawać sobie sprawę, że przyszły sposób postępowania ma ujawniać obraz nowego człowieka, dziecka Bożego. Konsekwencją tego wszystkiego, jak się wydaje, powinno być zerwanie z ciężkim grzechem, który ewentualnie był popełniany w ramach wcześniejszego sposobu życia. Przyjmując powyższe założenia, należy postawić pytanie, czy osoby żyjące w tzw. związkach nieregularnych, które nie mają z różnych powodów możliwości zawarcia po chrzcie małżeństwa sakramentalnego, powinny zostać do tego sakramentu, a także do bierzmowania i Komunii św. w ogóle dopuszczone. Odpowiedzi na to niezwykle złożone, trudne pytanie spróbujemy poszukać w najnowszej adhortacji papieża Franciszka pt. Amoris laetitia.

21 Obrzędy chrześcijańskiego wtajemniczenia dorostych dostosowane do zwyczajów diecezji polskich, Katowice 1988, nr 23, s. 26.

22 Zob. Obrzędy chrześcijańskiego wtajemniczenia..., nr 25, s. 27. 


\section{Próba oceny sytuacji osób żyjących w związkach nieregularnych w świetle adhortacji Amoris laetitia}

Dnia 19 marca 2016 roku papież Franciszek wydał posynodalną adhortację apostolską O miłości w rodzinie. Stanowi ona podsumowanie obrad XIV Zwyczajnego Zgromadzenia Ogólnego Synodu Biskupów, zakończonego 24 października 2015 roku. Już na początku dokumentu papież podkreśla, że nie wszystkie dyskusje doktrynalne, moralne czy duszpasterskie powinny być rozstrzygane interwencjami Magisterium. Konieczna jedność doktryny i działania Kościoła nie przeszkadza istnieniu różnych sposobów interpretowania pewnych aspektów nauczania ${ }^{23}$.

Dokument ten, jak się wydaje, stanowi klucz do rozwiązania problemu dopuszczania interesującej nas grupy osób do przyjmowania Eucharystii, a nawet wcześniej chrztu i bierzmowania. Dopuszczenie zależy od oceny moralnej ich postępowania, szczególnie współżycia seksualnego w związku funkcjonującym na wzór małżeństwa, które według doktryny katolickiej poza faktycznym małżeństwem stanowi materię grzechu ciężkiego.

Najpierw jednak zobaczmy, jakie związki mężczyzny i kobiety są nazywane w adhortacji nieregularnymi. Są zatem nimi związki cywilne, w których nie ma przeszkód, aby strony przystąpiły do sakramentu małżeństwa; dalej - cywilne po wcześniejszym rozwodzie (z przeszkodą uniemożliwiającą zawarcie małżeństwa kanonicznego); i w końcu związki osób, które mieszkają ze sobą jak małżonkowie, lecz nie łączy ich żaden związek formalny na wzór małżeństwa (tzw. konkubinaty). W cytowanym dokumencie czytamy, że należy do nich podejść duszpastersko, ukazując Bożą pedagogikę łaski w ich życiu, i pomagać w osiągnięciu pełni planu

23 Zob. Franciszek, Adhortacja apostolska Amoris laetitia [dalej:AL], 19.03.2016, n. 6 . 
Boga ${ }^{24}$. W sposób szczególny dokument papieski zwraca uwagę na osoby rozwiedzione żyjące w nowym związku, mogące znaleźć się w różnych sytuacjach, które nie powinny być katalogowane albo zbyt surowo oceniane bez odpowiedniego rozeznania osobistego i duszpasterskiego. Wśród nich wspomina się:

a) osoby żyjące w drugim związku, który z czasem się umocnił, z urodzonymi w nim dziećmi, sprawdzoną wiernością, wielkodusznym poświęceniem, zaangażowaniem w życie chrześcijańskie, świadomością nieprawidłowości swojej sytuacji i poważną trudnością, aby się z niego wycofać bez popadnięcia w nowe winy,

b)osoby, które podjęły wielki wysiłek, aby uratować swoje pierwsze, sakramentalne małżeństwo, ale doznały porzucenia,

c) osoby posiadające w sumieniu subiektywną pewność nieważności poprzedniego, nieodwracalnie zniszczonego już małżeństwa, które zawarły nowy związek ze względu na wychowanie istniejących z sakramentalnego małżeństwa dzieci ${ }^{25}$.

Katalog takich przykładów nie jest zamknięty.

Biorąc pod uwagę temat niniejszego opracowania, który odnosi się również do osób pragnących przyjąć chrzest, należy stwierdzić, iż mogą się one znajdować w nieregularnej sytuacji małżeńskiej, jeżeli zawarły kontrakt cywilny z rozwodnikiem wcześniej żyjącym w małżeństwie sakramentalnym albo też same uprzednio żyły w ważnym małżeństwie naturalnym, po czym zawarły kolejny związek, w którym ich sytuacja rodzinna nie pozwala na pozostawienie nowego partnera. Chodzi więc o kandydatów do chrztu niemogących po nim przystąpić do małżeństwa sakramentalnego.

Ojcowie synodalni obradujący nad problemami rodziny w $R e-$ latio Synodi z 2014 roku stwierdzają, że rozeznanie duszpasterzy zawsze powinno kierować się odpowiednim rozróżnieniem,

24 Zob. AL, n. 297.

25 Zob. AL, n. 298. 
ze spojrzeniem dobrze rozeznającym sytuację, ponieważ nie można tutaj znaleźć prostych odpowiedzi ${ }^{26}$. Natomiast papież Franciszek w Amoris laetitia stara się uświadomić, że stopień odpowiedzialności osób żyjących w tzw. związkach nieregularnych, a szczególnie w związkach cywilnych po rozpadzie małżeństwa sakramentalnego może być zróżnicowany, a jego ocena moralna w różnych przypadkach odmienna. Papież pisze w następujący sposób: „stopień odpowiedzialności nie jest równy w każdym przypadku". Stąd rozmowa z kapłanem na forum wewnętrznym przyczynia się do tworzenia prawidłowej oceny, co ułatwia możliwość pełniejszego uczestnictwa w życiu Kościoła oraz podjęcia konkretnych kroków sprzyjających takowemu uczestnictwu i je rozwijających ${ }^{27}$.

Jak zauważył autor niniejszego opracowania podczas dyskusji prowadzonej w Kościele przed wspominanym synodem biskupów, problem niedopuszczania rozwiedzionych po zawarciu nowego kontraktu cywilnego do sakramentów wiąże się przede wszystkim z ciągłym pozostawaniem przez nich w grzechu cudzołóstwa, uznawanego za grzech ciężki. Należy jednak zauważyć, iż do popełnienia tego rodzaju grzechu nie wystarcza sama ciężka jego materia, z którą w takim przypadku mamy niewątpliwie do czynienia. Potrzebna jest równocześnie świadomość i dobrowolność takiego postępowania. Jawi się zatem istotne pytanie: czy osoby posiadające Boże powołanie do życia w małżeństwie i rodzinie (ze wszystkimi tego konsekwencjami) oraz praktykujące wcześniej takie życie w małżeństwie rzeczywiście są w stanie po rozpadzie związku sakramentalnego, za który mogą absolutnie nie ponosić winy, dobrowolnie żyć już zawsze w celibacie - bezżeństwie

26 Zob. III Nadzwyczajne Zgromadzenie Ogólne Synodu Biskupów, Relatio Synodi, 18.10.2014, par. 25, 45 .

27 Zob. AL, n. 300. 
i wstrzemięźliwości seksualnej, wbrew wspomnianemu powołaniu otrzymanemu od Stwórcy? Jeżeli tak nie jest, czy uprawnione jest mówienie o pełnej dobrowolności popełnianego przez nich grzechu? ${ }^{28}$

Odpowiedź na to pytanie daje omawiany dokument papieski: „nie można już mówić, że wszyscy, którzy znajdują się w sytuacji tak zwanej nieregularnej, żyją w stanie grzechu śmiertelnego, pozbawieni łaski uświęcającej”. Osoba znająca dobrze normę moralną może mieć duże trudności w zrozumieniu zawartych w niej wartości albo też znaleźć się w określonych warunkach niepozwalających działać inaczej i podejmować inne decyzje bez zaciągania nowej winy. Tak więc mogą zaistnieć czynniki ograniczające zdolność podejmowania decyzji przez interesujące nas osoby ${ }^{29}$.

W Katechizmie Kościoła Katolickiego znajdujemy następujące twierdzenie:

Poczytalność i odpowiedzialność za działanie mogą zostać zmniejszone, a nawet zniesione, na skutek niewiedzy, nieuwagi, przymusu, strachu, przyzwyczajeń, nieopanowanych uczuć oraz innych czynników psychicznych lub społecznych ${ }^{30}$.

W myśl tego odpowiedzialność zmniejszają również niedojrzałość uczuciowa, nabyte nawyki, stany lękowe i inne czynniki psychiczne oraz społeczne ${ }^{31}$. Stąd w pewnych okolicznościach ludzie napotykają na poważne trudności, aby postępować inaczej, niż czynili to dotychczas (w sakramentalnym małżeństwie). Zatem rozeznanie duszpasterskie, które uwzględnia prawidłowo

28 Zob. Z. Janczewski, Przyjmowanie Eucharystii przez osoby żyjące w matżeństwach niesakramentalnych, w: Reddite ergo qua sunt caesaris caesari et qua sunt Dei Deo. Studia in honorem prof. Josephi Krukowski dedicata, Lublin 2015, s. 410.

29 Zob. AL, n. 301.

30 KKK 1735.

31 Zob. KKK 2352. 
uformowane sumienie, musi uwzględniać tego rodzaju sytuacje. Podobnie - skutki popełnionych czynów nie muszą zawsze być takie same ${ }^{32}$. Biorąc pod uwagę konkretne uwarunkowania, powinno się lepiej włączyć ludzkie sumienie do praktyki Kościoła w niektórych sytuacjach, obiektywnie odbiegających od katolickiego rozumienia małżeństwa. Sumienie może uznać nie tylko, że konkretna sytuacja obiektywnie nie odpowiada ogólnym postanowieniom Ewangelii - może również szczerze i uczciwie uznać, że to, co w danej chwili, jest wielkoduszną odpowiedzią, jaką można dać Bogu, odkrywając z jakąś pewnością moralną, że jest to dar wymagany od samego Boga, pośród złożoności ograniczeń, pomimo że nie jest to $\mathrm{w}$ pełni obiektywny ideał. Takie rozeznawanie jest procesem dynamicznym, pozwalającym z czasem na zrealizowanie ideału w pełniejszy sposób³.

Według Rocco Buttiglione novum adhortacji stanowi fakt, iż do tej pory mówiło się o domniemaniu całkowitej winy w kontekście grzechu, który popełniają osoby rozwiedzione i żyjące w nowych związkach. Teraz w stosunku do tego grzechu dopuszcza się aspekt subiektywny, jak ma to miejsce np. w przypadku zabójstwa, wyzysku pracowników i wszystkich innych grzechów. Chociaż rozwód i nowy związek obiektywnie pozostają złem, trzeba dobrze rozeznać, czy okoliczności nie zdejmują pełnej odpowiedzialności $\mathrm{z}$ danej osoby ${ }^{34}$.

Cytowane dokumenty papieskie zdają się więc uznawać, że niektóre osoby żyjące poza sakramentalnym związkiem małżeńskim nie popełniają grzechu ciężkiego ze względu na różne okoliczności łagodzące czy też czynniki niejako zmuszające je do takiego sposobu życia. Skoro w takich przypadkach nie występuje przesłanka

\footnotetext{
32 Zob. AL, n. 302.

33 Zob. AL, n. 303.

34 Zob. R. Buttiglione, wywiad z 1.06.2016, http://vaticanisider.lastampa.it/ vatican-insider-polacco/articoli/articoli/45221 (20.11.2016).
} 
dobrowolności popełnianego grzechu, konieczna, aby uznać go za ciężki, spowiednik, zgodnie z wielowiekową praktyką i nauczaniem doktrynalnym Kościoła, ma chyba prawo udzielić rozgrzeszenia, a przez to dopuścić do przyjęcia innych sakramentów.

\section{Dopuszczanie do sakramentów} wtajemniczenia osób żyjących w nieregularnych sytuacjach małżeńskich

Jakie są konsekwencje zmiany spojrzenia Kościoła na niektóre osoby żyjące jak małżeństwo w związkach niesakramentalnych? Skoro nie zawsze takie postępowanie musi się łączyć z ciągłym życiem w stanie grzechu ciężkiego, czy wolno je dopuszczać do sakramentów wtajemniczenia chrześcijańskiego? Kluczem do odpowiedzi na to pytanie jest, jak się wydaje, ewentualna możliwość przyjmowania przez nie Eucharystii. Skoro ktoś mógłby przystępować do Komunii św., to być może wolno mu też udzielić bierzmowania, a wcześniej ochrzcić.

Papież Franciszek w odniesieniu do Komunii św. pisze w interesującej nas adhortacji, że ze względu na uwarunkowania i czynniki łagodzące możliwe jest, iż pośród pewnej obiektywnej sytuacji grzechu osoba, która nie jest subiektywnie albo w pełni winna, może żyć w łasce Bożej, kochać, wzrastać w życiu łaski i miłości, otrzymując w tym celu pomoc Kościoła. Eucharystia nie jest nagrodą dla doskonałych, ale szlachetnym lekarstwem dla słabych ${ }^{35}$. Sytuację wcześniej powinien rozeznać spowiednik lub kierownik duchowy. Rozeznanie polega na poznaniu aktualnego statusu rodzinnego danej osoby lub obojga partnerów związanych związkiem „nieregularnym”. W pierwszej fazie, jak się wydaje, właściwym będzie tutaj forum pozasakramentalne. Należy wtedy ustalić, czy nie ma podstaw do wniesienia skargi o stwierdze-

35 Zob. AL, n. 305. 
nie nieważności poprzedniego (kanonicznego) małżeństwa albo prośby o dyspensę od małżeństwa niedopełnionego ${ }^{36}$. Jeżeli takie podstawy nie istnieją, spowiednik lub kierownik duchowy musi zapoznać się dokładnie z przyczynami rozpadu małżeństwa, powodami zawarcia nowego związku, przebiegiem życia w nim małżonków, sytuacją dzieci, kwestią współżycia intymnego. Trzeba się zorientować, czy nie występują jakieś czynniki „łagodzące”, sprawiające, że w obiektywnej sytuacji ciężkiego grzechu cudzołóstwa dana osoba nie jest winna subiektywnie lub nie ponosi pełnej winy. Jak pisze Góralski, w procesie rozpoznawania sytuacji małżonka chodzi finalnie o ustalenie:

1) czy w jej zaistnieniu (trwanie w obiektywnym grzechu cudzołóstwa) ponosi on poważną winę,

2) czy istnieją czynniki łagodzące, powodujące brak u niego subiektywnej lub pełnej winy,

3) czy istnieją określone warunki niepozwalające małżonkowi działać inaczej, bez zaciągnięcia nowej, poważnej winy po opuszczeniu aktualnego partnera.

Od ustalenia stanu faktycznego zależy końcowa decyzja o udzieleniu rozgrzeszenia ${ }^{37}$.

Wśród komentatorów papieskiego dokumentu istnieją tacy, którzy uważają, iż odnosi się on do sytuacji, kiedy rozwiedzeni małżonkowie trwający w nowym związku, po odpowiednim rozeznaniu z pomocą spowiednika lub kierownika duchowego, zdecydowali się na życie „jak brat z siostrą”, zachowując całkowitą wstrzemięźliwość seksualną, a później nie udało im się dotrzymać swojego postanowienia ${ }^{38}$. Takie spojrzenie nie wydaje się jednak

36 Zob. Z. Janczewski, Przyjmowanie Eucharystii..., s. 410.

37 Zob. W. Góralski, Adhortacja apostolska „Amoris laetitia” papieża Franciszka. Prezentacja dokumentu z komentarzem do nn. 300-308, Płock 2016, s. 59-6o.

38 Należą do nich kard. E. Antonelli i W. Góralski, por. W. Góralski, Adhortacja apostolska..., s. 69-75. 
do końca słuszne, ponieważ dopuszczanie do Komunii św. tych osób przewidywała już dawno adhortacja apostolska Familiaris consortio papieża Jana Pawła II z 22 listopada 1981 roku39.

Bliższa zamysłowi papieża Franciszka jest interpretacja zawarta w dokumencie biskupów regionu duszpasterskiego Buenos Aires z 5 września 2016 roku, zawierająca również wskazówki na temat osób rozwiedzionych i trwających w nowych związkach, nawiązująca do adhortacji Amoris laetitia. W dokumencie czytamy, że należy mówić nie o „zgodzie” na dostęp interesujących nas osób do sakramentów, a raczej o „procesie rozeznania” z udziałem duszpasterza. Droga ta nie musi ostatecznie prowadzić do udzielenia im sakramentów, ale kierować ku innym formom większej integracji z życiem Kościoła, np. przez uczestnictwo w różnorodnych grupach duszpasterskich czy zaangażowanie w posługi kościelne. Jeśli jest to wykonalne w konkretnych warunkach, szczególnie, gdy oboje znajdują się na „drodze wiary”, można im zaproponować życie we wstrzemięźliwości seksualnej, otwierające drogę do sakramentu pojednania. Jeżeli natomiast w konkretnym przypadku istnieją ograniczenia zmniejszające odpowiedzialność i winę, szczególnie kiedy osoba uważa, że popadłaby w kolejne winy ze szkodą dla dzieci z nowego związku, Amoris laetitia otwiera możliwość dopuszczenia do sakramentów pojednania i Eucharystii, ponieważ pozwolą one danej osobie na dalsze dojrzewanie i wzrost mocą łaski. Takiej możliwości nie należy jednak uznawać za bezwarunkowe dopuszczanie do sakramentów ${ }^{40}$.

W tym miejscu należy zauważyć, że następca św. Piotra, Franciszek, w liście z 8 września 2016 r. skierowanym do twórców

39 Zob. Jan Paweł II, Adhortacja apostolska Familiaris consortio, 22.11.1981, n. 84 .

40 Zob. Obispos de la Region Pastoral Buenos Aires, Criterios básicos para la aplicación del capítulo VIII de Amoris laetitia, http://infocatolica.com/?t=ic\&cod= $27336(20.11 .2016)$ 
cytowanego dokumentu stwierdza, iż ,jest on bardzo dobry i doskonale wyjaśnia znaczenie rozdziału viıı". Autor stanowczo podkreśla, że „nie istnieją inne interpretacje tego fragmentu adhortacji"41. Uznaje zatem interpretację biskupów argentyńskich niejako za swoją.

Czy można powiedzieć, że papież Franciszek zmienił doktrynę Kościoła na temat małżeństwa i jego nierozerwalności? Taka teza jest absolutnie nieuzasadniona. Wielowiekowa doktryna nie została zmieniona i nie może się zmienić w przyszłości. Zmiana następuje, jak się wydaje, jedynie w samej dyscyplinie, która wciąż ewoluuje, dopasowując się do konkretnych warunków życia człowieka w czasach mu współczesnych. Jeszcze na początku xx wieku każdy grzech dotyczący szóstego przykazania Bożego był uznawany za śmiertelny, a osoby żyjące jak brat z siostrą w związku cywilnym, po rozpadzie małżeństwa sakramentalnego, nie posiadały prawa do przyjmowania Komunii św. W drugiej połowie wieku to się zmieniło. Papież zdaje się czynić kolejny krok naprzód, ukazując nowy sposób oceny moralnej postępowania interesujących nas osób w konkretnej, indywidualnej sytuacji ${ }^{42}$.

Wracając do problemu postawionego na początku powyższego przedłożenia: czy osobom znajdującym się w tzw. związkach nieregularnych można udzielać sakramentów wtajemniczenia chrześcijańskiego? W odniesieniu do przyjęcia do Kościoła i kolejnego ich sprawowania (chrztu, bierzmowania, Eucharystii), tak jak to zostało ukazane na początku, pierwotnie nie czyniono tego w przypadku prowadzenia przez kandydata życia niezgodnego

41 Francisco, Los Obispos de la Region Pastoral Buenos aires Mons. S. A. Fenoy Delegato de la Region, w: W. Góralski, Adhortacja apostolska..., przyp. 55, s. 8o-81. 42 Zob. Z. Janczewski, Udzielanie Komunii św. osobom rozwiedzionym? Analiza adhortacji „Amoris laetitia” papieża Franciszka, „Prawo Kanoniczne” 59 (2016) nr 2, s. 53 . 
z zasadami chrześcijaństwa. Od wielu jednak stuleci przyjęcie do Kościoła jest łatwiejsze, ponieważ wspólnota poprzez chrzest stara się pozyskać kolejnych członków, potencjalnie umożliwiając im rozpoczęcie nowej drogi wiodącej do zbawienia. Ich salus animarum staje się suprema lex. W przypadku interesujących nas osób w praktyce czasami wyjątkowo dopuszczało się je do chrztu, bierzmowania i jednorazowo do Komunii św.

Kluczem do rozwiązania interesującego nas problemu jest, jak się wydaje, odpowiedź na pytanie, czy osoby znajdujące się w nieregularnej sytuacji małżeńskiej będą mogły później w pełni uczestniczyć w życiu Kościoła, szczególnie regularnie przystępować do Eucharystii. Przyjmowanie tego sakramentu świadczy bowiem niejako o tym, czy ktoś w pełni uczestniczy w duchowym życiu wspólnoty (comunio) Kościoła rzymskokatolickiego. Jeśli ta wspólnota udziela mu Komunii św., to znaczy, że jest jej pełnoprawnym członkiem. Stąd jeżeli po przeprowadzeniu starannego wglądu w sytuację rodzinną oraz stan duchowy kandydata do chrztu dojdzie się do wniosku, iż po jego otrzymaniu pojawi się możliwość dopuszczania go do Komunii św., należałoby, zwłaszcza biorąc pod uwagę wspomnianą zasadę salus animarum suprema lex, zgodzić się na udzielenie chrztu.

A zatem jeśli w świetle omawianego papieskiego dokumentu przyjmuje się, że niektóre $\mathrm{z}$ interesujących nas osób nie żyją w grzechu ciężkim, wydaje się, że w takiej sytuacji nie istnieje przeszkoda zabraniająca ich ochrzczenia, bierzmowania i udzielania Komunii (nie tylko jednorazowej). W przypadku kiedy zostały ochrzczone już wcześniej, tym bardziej można je bierzmować. W każdym razie przy okazji porady duchowej lub spowiedzi nie można nakłaniać danej osoby do porzucenia dotychczasowego sposobu życia, o ile będzie się to wiązało z zaciągnięciem nowej, ciężkiej winy moralnej w stosunku do potomstwa istniejącego z obecnego związku czy do innych osób. Na to przynajmniej 
wskazuje Amoris laetitia ${ }^{43}$. Duszpasterzom absolutnie nie wolno przecież namawiać do popełnienia kolejnego grzechu.

Na zakończenie należy stanowczo podkreślić, że dopuszczanie do sakramentów wtajemniczenia mogłoby być traktowane jedynie jako sytuacja wyjątkowa i nadzwyczajna, a nie - rutynowe działanie duszpasterskie.

\section{Zakończenie}

Zazwyczaj przed przyjęciem sakramentów wtajemniczenia chrześcijańskiego przeprowadza się odpowiednie przygotowanie kandydatów. Cały proces przygotowania i przysposobienia dorosłych do chrztu dokonuje się w ramach specjalnie zorganizowanego w tym celu katechumenatu. Jeżeli jakaś poważna racja nie stoi na przeszkodzie, dorosły zaraz po chrzcie powinien zostać bierzmowany i uczestniczyć w Eucharystii, przyjmując Komunię św. Wśród wymogów do chrztu istnieje potrzeba wzbudzenia w sobie żalu za dotychczas popełnione grzechy. Natomiast do bierzmowania zdatnym jest chrześcijanin, który wcześniej nie przyjął tego drugiego z sakramentów wtajemniczenia. Aby przystąpienie do sakramentu było jednak godziwe, oprócz używania rozumu i odpowiedniego pouczenia kandydat ma być właściwie dysponowany - i o ile bierzmowanie nie jest połączone z chrztem, musi odnowić przyrzeczenia chrzcielne. Do Komunii św. nie może przystępować osoba posiadająca świadomość ciążącego na jej sumieniu grzechu ciężkiego. Grzech taki powinien być najpierw odpuszczony podczas sakramentu pokuty. Jeżeli jednak Komunia jest udzielana w triadzie sakramentów wtajemniczenia, podobnie jak w przypadku bierzmowania uznaje się, że przyjmujący posiada wspomnianą dyspozycję. Należy zauważyć, iż specyfiką katechumenatu, przygotowującego do chrztu i pozostałych sakramentów

43 Zob. AL, n. 298 i 301. 
wtajemniczenia, jest przyjęcie formy stanu, formy bycia chrześcijaninem, jeszcze przed momentem pełnego włączenia do Kościoła. Proces przygotowania dorosłych do przyjęcia chrztu i pozostałych sakramentów wtajemniczenia zarówno w czasach apostolskich, wczesnego chrześcijaństwa, jak i obecnie wymaga koniecznie zmiany życia kandydata. Stąd czasami prawo kościelne zabrania, aby sakramentu udzielić proszącemu, który w dalszym ciągu będzie żył na sposób osób niewierzących.

Problem możliwości udzielania interesujących nas sakramentów dotyczy między innymi osób żyjących w nieregularnych sytuacjach małżeńskich. W najnowszej adhortacji Amoris laetitia papież Franciszek stara się uświadomić, że stopień odpowiedzialności osób żyjących w tzw. związkach nieregularnych, a szczególnie w związkach cywilnych po rozpadzie małżeństwa sakramentalnego może być zróżnicowany, a ocena moralna w różnych przypadkach inna. „Nie można już mówić, że wszyscy, którzy znajdują się w sytuacji tak zwanej nieregularnej, żyją w stanie grzechu śmiertelnego, pozbawieni łaski uświęcającej”. Osoba znająca dobrze normę moralną może mieć duże trudności w zrozumieniu zawartych w niej wartości albo też znaleźć się w określonych warunkach niepozwalających działać inaczej i podejmować decyzje bez zaciągania nowej winy. Tak więc czasami istnieją czynniki ograniczające zdolność podejmowania decyzji przez interesujące nas osoby. Novum adhortacji stanowi fakt, iż do tej pory mówiło się o domniemaniu całkowitej winy w kontekście grzechu, jaki popełniają osoby rozwiedzione i żyjące w nowych związkach. Teraz w stosunku do tego grzechu dopuszcza się aspekt subiektywny. Chociaż rozwód i kolejny związek obiektywnie pozostają złem, trzeba dobrze rozeznać, czy okoliczności nie zdejmują pełnej odpowiedzialności z danej osoby. Papież Franciszek w odniesieniu do Komunii św. pisze w interesującej nas adhortacji, że ze względu na uwarunkowania i czynniki łagodzące możliwe jest, iż pośród 
pewnej obiektywnej sytuacji grzechu osoba, która nie jest subiektywnie albo w pełni winna, może żyć w łasce Bożej, kochać, wzrastać w życiu łaski i miłości, otrzymując w tym celu pomoc Kościoła. Eucharystia nie jest nagrodą dla doskonałych, ale szlachetnym lekarstwem dla słabych.

Istotną dla całego Kościoła interpretację adhortacji Amoris laetitia zawiera dokument biskupów regionu duszpasterskiego Buenos Aires z 5 września 2016 roku, ze wskazówkami na temat osób rozwiedzionych i trwających w nowych związkach. Biskupi argentyńscy stwierdzają, że należy mówić nie o „zgodzie” na dostęp interesujących nas osób do sakramentów, a raczej o „procesie rozeznania” z udziałem duszpasterza. Droga ta wcale nie musi ostatecznie prowadzić do udzielenia im sakramentów. Jeżeli jednak w konkretnym przypadku istnieją ograniczenia zmniejszające odpowiedzialność i winę, szczególnie kiedy dana osoba uważa, że popadłaby w kolejne winy ze szkodą dla dzieci z nowego związku, Amoris laetitia otwiera możliwość dopuszczenia do sakramentów pojednania i Eucharystii, ponieważ pozwolą one na dalsze dojrzewanie i wzrost mocą łaski. Takiej możliwości nie należy jednak uznawać za bezwarunkowe dopuszczanie do sakramentów. Papież Franciszek w liście z 8 września 2016 roku skierowanym do twórców cytowanego dokumentu stwierdza, iż "jest on bardzo dobry i doskonale wyjaśnia znaczenie rozdziału viıı”. Autor stanowczo podkreśla, że „nie istnieją inne interpretacje tego fragmentu adhortacji”. Uznaje zatem interpretację biskupów argentyńskich niejako za swoją.

Jeżeli w świetle papieskiej adhortacji przyjmuje się, że niektóre osoby znajdujące się w nieregularnej sytuacji małżeńskiej nie żyją w grzechu ciężkim, wydaje się, że w takich przypadkach nie istnieje również przeszkoda zabraniająca ich ochrzczenia, bierzmowania i udzielania Komunii (nie tylko jednorazowej). Jeśli jednak zostały ochrzczone już wcześniej, tym bardziej można 
je bierzmować. W każdym razie przy okazji porady duchowej lub spowiedzi spowiednik lub kierownik duchowy nie może nakłaniać danej osoby do porzucenia dotychczasowego sposobu życia rodzinnego, o ile będzie się to wiązało z zaciągnięciem nowej, ciężkiej winy moralnej.

Jak pisze jezuita James Martin, Kościół potrzebuje nieustannie się odnawiać, doceniając ważną rolę, jaką odgrywa w przeżywaniu wiary instytucja indywidualnego sumienia. Większość katolików wie również, że powinność słuchania głosu sumienia dotyczy jego „dobrze uformowanej” postaci, to znaczy tej, która zna i akceptuje Ewangelię i nauczanie Kościoła oraz gotowa jest do wprowadzania tej wiedzy w czyn. Krytycy adhortacji Franciszka nie pojmują, że Bóg może współdziałać z człowiekiem w bezpośredni sposób. Bóg porusza ludzi, pociesza, przynagla. Bóg pomaga im zrozumieć Ewangelię oraz nauczanie Kościoła w kontekście ich osobistego doświadczenia. Ostatecznie Bóg pomaga im podejmować dobre decyzje $\mathrm{e}^{44}$.

SUMMARY

\section{Admission to the sacraments of Christian initiation of the persons who live in an irregular marriage situation}

In the modern world many divorced people live with a new partner in a relationship similar to marriage. They cannot contract valid and sacramental

44 Zob. J. Martin sJ, What Some Critics of 'Amoris Laetitia'Are Missing, transl. J. Mikuczewski,http://m.deon.pl/religia/kosciol-i-swiat/komentarze/art,2415,co-umykaniektorym-krytykom-adhortacji-franciszka.html (21.10.2016). 
marriage in Roman Catholic Church. This article shows the situation of those people in regard to admission to the sacrament of baptism, confirmation and Holy Communion, after pope Francis' new document Amoris laetitia. The first part of the article shows the basis of admission to sacraments of Christian initiation in canon law. The next one is about preparation of an adult person to those sacraments. The third is trying to judge situation of persons in an irregular marriage situation in Amoris laetitia. Last part of the article shows today's possibilities of admission of a person in an irregular marriage situation to the sacraments of initiation.

Keywords: sacraments of Christian initiation, baptism, confirmation, Holy Communion, marriage, irregular marriage situation, admission to sacraments

Zbigniew Janczewski, Dopuszczenie do sakramentów wtajemniczenia osoby w nieregularnej sytuacji małżeńskiej, w: Dyskusje nad „Amoris laetitia”, red. Piotr Kroczek, Kraków 2017, s. 47-68 (Annales Canonici Monographiae, 6).

DOI: http://dx.doi.org/10.15633/9788374386463.04 